Case Report

\title{
Signet Cell Carcinoma of Colon in a Nineteen-Year-Old Patient: A Case Report
}

\author{
Özgül Pamukçu, ${ }^{1}$ Fatih Selcukbiricik, ${ }^{2}$ Ahmet Bilici, ${ }^{2}$ Damlanur Sakız, ${ }^{3}$ \\ Osman Özdoğan, ${ }^{4}$ and Fatih Borlu' ${ }^{1}$ \\ ${ }^{1}$ Department of Internal Medicine, Şişli Etfal Training Hospital, 34360 Istanbul, Turkey \\ ${ }^{2}$ Department of Medical Oncology, Şişli Etfal Training Hospital, 34360 Istanbul, Turkey \\ ${ }^{3}$ Department of Pathology, Sişli Etfal Training Hospital, 34360 Istanbul, Turkey \\ ${ }^{4}$ Department of Gastroenterohepatology, Şişli Etfal Training Hospital, 34360 Istanbul, Turkey
}

Correspondence should be addressed to Özgül Pamukçu; pamgul@hotmail.com

Received 11 December 2012; Accepted 4 January 2013

Academic Editors: S. B. Chichareon and K. Tanaka

Copyright (C) 2013 Özgül Pamukçu et al. This is an open access article distributed under the Creative Commons Attribution License, which permits unrestricted use, distribution, and reproduction in any medium, provided the original work is properly cited.

\begin{abstract}
Signet cell carcinoma, which is a subtype of adenocarcinoma, usually originates from the stomach. However, it can also originate from the colon, rectum, gallbladder, pancreas, urinary bladder, and breast. We represent a 19-year-old boy diagnosed with signet cell tumour while he was being evaluated for an initial diagnosis of inflammatory bowel disease.
\end{abstract}

\section{Introduction}

Globally, CRC is the third most commonly diagnosed cancer in males and the second in females, with over 1.2 million new cases and 608,700 deaths estimated to have occurred in 2008 [1]. According to the World Health Organization data, about 608.000 deaths from colorectal cancer are estimated worldwide, accounting for $8 \%$ of all cancer deaths, making it the fourth most common cause of death from cancer [2].

Colorectal cancer is a common malignancy in adults which peaks around 6th or 7 th decades of life. However, less than $20 \%$ of the colorectal cancer cases can be seen before the age of 50 [3]. And in USA it was reported that less than $1 \%$ of all cancers are colorectal cancers in the first two decades of life $[4,5]$. While signet cell carcinoma is a poor differentiated type of adenocarcinoma and behaves more aggresively than ordinary adenocarcinoma of colon, it is more common in younger patients (especially under 40) compared to other types [6].

Because of the lack of awareness at early age and the aggressive characteristic of the tumour, signet ring cell carcinomas of the colon mostly present as advanced stage. In this case report, we report a 19-year-old boy who we were evaluating for an initial diagnosis of inflammatory bowel disease was our first diagnosis. We have interned patient with that initial diagnosis.

\section{Case}

A 21-year-old boy who has been evaluated in emergency service with abdominal pain was referred to our outpatient clinic because of the reason that there was seen edema and inflammation around the ileal wall and some collection regarding the initial diagnosis of inflammatory bowel disease in the CT scan performed to exclude acute abdomen. The patient has no family history of any cancer. In his physical examination, mildtenderness has been detected in the right lower quadrant and periumblical site of the abdomen. His bowel sounds were normal and in his rectal examination, there was a formed stool without blood. In his laboratory results, pathological results were as follows: CRP: 25; ESR: 22 and fecal occult blood test was positive. In his CT/CT enterography there was seen free subhepatic and pelvic abdominal fluid; asimetric thickening in the sigmoid colon walls; derangement of bowels and peritoneum. According to these findings the radiologists pointed that it must be evaluated not only for inflammatory bowel disease but also 


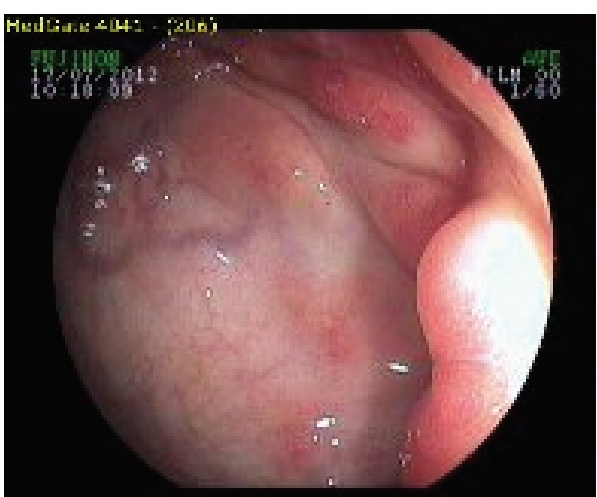

(a)

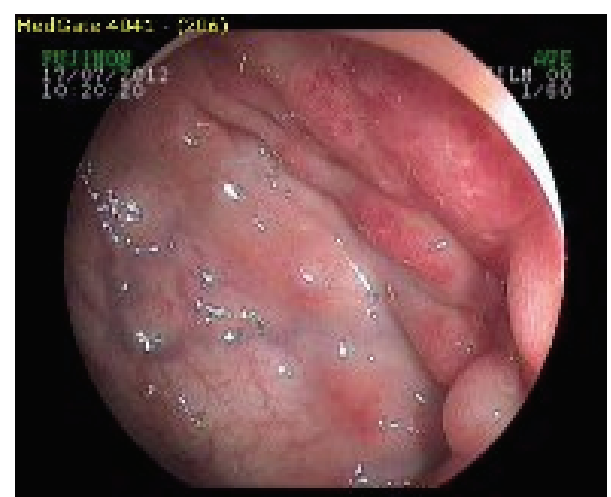

(b)

Figure 1: (a), (b) Colonoscopic view of the signet cell tumour in sigmoid colon. The colonoscopy could not been completed according to the obstruction.

for the diseases involve peritoneum. Then colonoscopy and gastroscopy were performed and while there was no pathological sign in gastroscopy, an obstruction in sigmoid colon has been detected by colonoscopy (Figures 1(a), and 1(b)). The biopsies were taken. Before the pathological investigation has been completed, patient was presented with subileus according to the obstruction of sigmoid colon. Placement of a metal stent to the sigmoid colon was tried but it was not successful according to the hardness of the tumour. Biopsy results were reported as signet ring cell carcinoma of sigmoid colon (Figure 2). Signet cell carcinoma cells were also seen in the abdominal fluid which we have obtained after the pathological diagnosis. Afterwards, the PET/CT scan was performed and it also showed peritonitis carcinomatosa with a significant omental cake. As the patient was accepted as inoperable with an advanced stage, patient underwent the surgery for the palliative colostomy. FOLFOX regimen which includes 5 Fluoruracil, calcium folinate, oxaliplatin, and bevacizumab (FOLFOX + Bevacizumab) has been started with the diagnosis of metastatic colon cancer. The patient is still undergoing treatment.

\section{Discussion}

Signet cell cancer of the colon is a rare subtype of colon cancer, where abundant intracytoplasmic mucin pushes the nucleus to the periphery giving a signet ring appearance. Primary colorectal signet cell carcinoma is diagnosed when the following criteria are satisfied. Firstly, the tumor must be primary, histological material must be adequate and signet ring cells present in more than $50 \%$ of the cancer [7]. Our patient could have been accepted as a primary signet cell carcinoma according to these criteria as we have ruled out any cancer in another primary site.

More than $96 \%$ of signet-ring cell carcinomas arise in the stomach, and the rest occurred in other organs [8]. Signet ring cell carcinoma accounts for less than $1 \%$ of all colon cancers [9].

Primary signet-ring cell carcinoma of the colon and rectum which was described by Laufman and Saphir in 1951

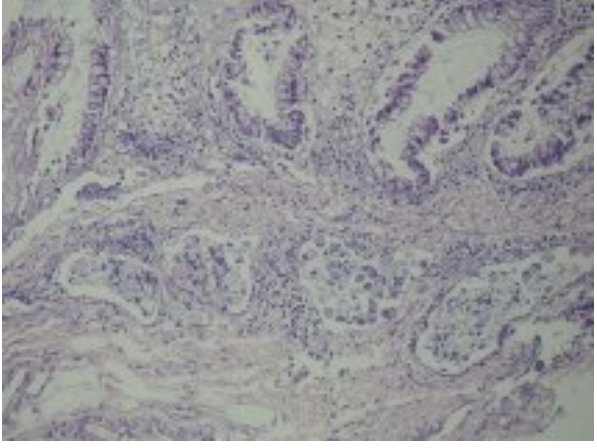

FIGURE 2: A number of signet cells regarding signet cell carcinoma can be seen in the submucosal layer of vascular structures. (H\&E; 100x).

[11] is so rare that its incidence was reported as $0.01 \%-2.6 \%$ [12].

Signet ring cell tumours have an aggressive clinical course and a poor prognosis. There is high incidence of peritoneal metastases and relatively low incidence of hepatic metastases, a characteristic feature distinguishing colorectal signet-ring cell carcinoma from nonsignet colorectal carcinoma [13].

In the literature, signet-ring cell carcinomas tend to affect predominately young individuals and HNPCC patients [9]. However Zambrano et al. reported that they have not found relation between the HNPCC and primary signet cell carcinoma of rectum and colon [14]. Patients are often noted to be younger compared to the patients with non-signet cell tumors of the colon. Median age is about 59 years when compared to the nonsignet cell cancer, where the median age is about 61 years [15]. Our patient was one of the youngest patients in literature excluding the the pediatric population where $68 \%$ of all colorectal cancers show mucinous characteristics reported by the review of Hill et al. [16]. However also in children a limited number of colorectal carcinoma have been reported and while most of these cases are teens, the youngest one reported was a 9-month-old baby [17]. The cases with colon cancer in young patients in the literature are shown in the Table 1. 
TABLE 1: Reported cases with colon cancer in young patients.

\begin{tabular}{|c|c|c|c|c|c|}
\hline & $\begin{array}{l}\text { Age-sex } \\
\text { (m: male } \\
\text { f: female) }\end{array}$ & Symptom & $\begin{array}{l}\text { Site of tumour and } \\
\text { histology }\end{array}$ & Treatment & Survival \\
\hline Shih et al. [2] & $15, \mathrm{~m}$ & $\begin{array}{l}\text { Epigastric pain, } \\
\text { decreased apetite, } \\
\text { mild watery diarrhea }\end{array}$ & $\begin{array}{l}\text { Hepatic flexura of the } \\
\text { colon/mucinous type } \\
\text { adenocarcinoma }\end{array}$ & $\begin{array}{c}\text { Palliative } \\
\text { ileosigmoidostomy } \\
\text { Chemo-ND* }\end{array}$ & 1 month after surgery \\
\hline Tung et al. [6] & $31 \mathrm{y}, \mathrm{m}$ & $\begin{array}{c}\text { Persistent abdominal pain, } \\
\text { vomiting } \\
\text { Subacute intestinal } \\
\text { obstruction }\end{array}$ & $\begin{array}{l}\text { Rectosigmoid side of colon } \\
\text { signet ring cell carcinoma }\end{array}$ & $\begin{array}{c}\text { Radical surgical resection } \\
\text { Chemo-ND }\end{array}$ & $\mathrm{ND}^{*}$ \\
\hline $\begin{array}{l}\text { Messerini et al. } \\
{[7]}\end{array}$ & $10 \mathrm{y}, \mathrm{f}$ & $\begin{array}{l}\text { Subacute intestinal } \\
\text { obstruction, } \\
\text { recurrent vague abdominal } \\
\text { pain }\end{array}$ & $\begin{array}{l}\text { Descending and sigmoid } \\
\text { colon/poorly differentiating } \\
\text { mucin secreting } \\
\text { adenocarcinoma }\end{array}$ & $\begin{array}{l}\text { Left hemicolectomy; } \\
5 \mathrm{FU}+\text { Leucovorin }\end{array}$ & $\begin{array}{c}8 \text { months-recurrence } \\
\text { free as known. } \\
\text { No further } \\
\text { information. }\end{array}$ \\
\hline Fu et al. [8] & $16 y, f$ & $\begin{array}{l}\text { Abdominal pain, } \\
\text { rectal bleeding }\end{array}$ & $\begin{array}{l}\text { Sigmoid colon/signet ring } \\
\text { cell carcinoma }\end{array}$ & $\begin{array}{c}\text { Hemicolectomy + anterior } \\
\text { resection } \\
\text { Chemo-ND }\end{array}$ & ND \\
\hline Thota et al. [9] & $17 \mathrm{y}, \mathrm{m}$ & $\begin{array}{l}\text { Progressive right sided } \\
\text { abdominal pain and } \\
\text { swelling }\end{array}$ & $\begin{array}{l}\text { Ascending colon/signet } \\
\text { ring cell carcinoma }\end{array}$ & $\begin{array}{c}\text { Right colon resection }+ \\
\text { ileocolic anastomosis } \\
\text { FOLFOX-6 }\end{array}$ & 1 year \\
\hline Ko et al. [10] & $13, \mathrm{~m}$ & $\begin{array}{l}\text { Abdominal pain, } \\
\text { poor apetite, } \\
\text { abdominal fullness }\end{array}$ & $\begin{array}{l}\text { Ascending colon/signet cell } \\
\text { carcinoma }\end{array}$ & $\begin{array}{c}\text { Right hemicolectomy; } \\
5 \mathrm{FU}+ \\
\text { Leucovorin } \\
\text { Levamisole } \\
\text { Sisplatin }\end{array}$ & 1 year, 5 months. \\
\hline Özgül et al. & $19 \mathrm{y}, \mathrm{m}$ & $\begin{array}{l}\text { Persistant abdominal pain, } \\
\text { weight loss }\end{array}$ & $\begin{array}{l}\text { Sigmoid colon/signet ring } \\
\text { cell carcinoma }\end{array}$ & $\begin{array}{c}\text { Palliative colostomy } \\
\text { FOLFOX- } 6+ \\
\text { bevacizumab }\end{array}$ & ND \\
\hline
\end{tabular}

${ }^{*} \mathrm{ND}$ : not determined.

The most common presenting symptom in colorectal signet cell tumour is abdominal pain. Other symptoms include rectal bleeding, change on bowel habits, and weight loss [18]. The symptoms can mimic inflammatory bowel disease. Our patient's symptoms were not only similar to inflammatory bowel disease clinically with the rectal bleeding and abdominal pain; but also radiologically the initial CT scan let us considering inflammatory bowel disease.

In 2005, Achneck et al. also reported a signet ring cell carcinoma case which was treated as an inflammatory bowel disease initially [19]. The infrequency of the disease among the young population makes the diagnosis more difficult and the prognosis less favorable.

As it was reported that the intestinal type-especially the signet cell type-of gastric cancers has increased over the last 50 years, it must be considered in the patients present with persistent abdominal pain even if the patient is young [15].

\section{References}

[1] A. Jemal, F. Bray, M. M. Center, J. Ferlay, E. Ward, and D. Forman, "Global cancer statistics," CA: A Cancer Journal for Clinicians, vol. 61, no. 2, pp. 69-90, 2011.

[2] GLOBOCAN 2008 (IARC), Section of Cancer Information, 2012.

[3] A. Afroza, S. Hasan, M. Rukunuzzaman, S. A. Hussain, and R. Amin, "Carcinoma-rectum in an 11 years old boy," Mymensingh Medical Journal, vol. 16, no. 2, pp. S70-S72, 2007.
[4] A. Andersson and L. Bergdahl, "Carcinoma of the colon in children: a report of six new cases and a review of the literature," Journal of Pediatric Surgery, vol. 11, no. 6, pp. 967-971, 1976.

[5] S. K. Gupta and R. L. Caballes, "Adenocarcinoma of colon in a child," Journal of Pediatric Gastroenterology and Nutrition, vol. 5, no. 6, pp. 973-976, 1986.

[6] S. Y. Tung, C. S. Wu, and P. C. Chen, "Primary signet ring cell carcinoma of colorectum: an age-and sex-matched controlled study," American Journal of Gastroenterology, vol. 91, no. 10, pp. 2195-2199, 1996.

[7] L. Messerini, A. Palomba, and G. Zampi, "Primary signet-ring cell carcinoma of the colon and rectum," Diseases of the Colon and Rectum, vol. 38, no. 11, pp. 1189-1192, 1995.

[8] K. I. Fu, Y. Sano, S. Kato et al., "Primary signet-ring cell carcinoma of the colon at early stage: a case report and a review of the literature," World Journal of Gastroenterology, vol. 12, no. 21, pp. 3446-3449, 2006.

[9] R. Thota, T. Tashi, W. Gonsalves et al., "Primary signet ring cell carcinoma of colon: retrospective analysis of VACCR database," Journal of Clinical Oncology, vol. 29, supplement 4, abstract 58, 2011.

[10] L. S. Ko, L. H. Lin, and D. F. Chen, "Carcinoma of the colon in a child," Zhonghua Min Guo Xiao Er Ke Yi Xue Hui Za Zhi, vol. 36, no. 3, pp. 227-230, 1995.

[11] H. Laufman and O. Saphir, "Primary linitis plastica type of carcinoma of the colon," A.M.A. Archives of Surgery, vol. 62, no. 1, pp. 79-91, 1951. 
[12] J. H. Wang, D. J. Liang, C. H. Fang, and S. Y. Chou, "Signet ring cell carcinoma of rectum: case report," Cheng Ching Medical Journal, vol. 3, no. 1, pp. 50-53, 2005.

[13] H.-L. Sim, K.-Y. Tan, P.-L. Poon, and A. Cheng, "Primary rectal signet ring cell carcinoma with peritoneal dissemination and gastric secondaries," World Journal of Gastroenterology, vol. 14, no. 13, pp. 2118-2120, 2008.

[14] S. C. Zambrano, S. j. Lihon, and A. Zavaleta, "Carcinoma de células en anillo de sello del colon yrecto en el Instituto Nacional de Enfermedades Neoplásicas," Revista de Gastroenterología del Perú, vol. 24, pp. 234-237, 2004.

[15] D. E. Henson, C. Dittus, M. Younes, H. Nguyen, and J. AlboresSaavedra, "Differential trends in the intestinal diffuse types of gastric carcinoma in the United States, 1973-2000: increase in the signet ring cell type," Archives of Pathology and Laboratory Medicine, vol. 128, no. 7, pp. 765-770, 2004.

[16] D. A. Hill, W. L. Furman, C. A. Billups et al., "Colorectal carcinoma in childhood and adolescence: a clinicopathologic review," Journal of Clinical Oncology, vol. 25, no. 36, pp. 58085814, 2007.

[17] W. H. Kern and W. C. White, "Adenocarcinoma of the colon in a 9-month-old infant; report of a case," Cancer, vol. 11, no. 4, pp. 855-857, 1958.

[18] J. Marone, S. Patel, M. Page, and P. Cheriyath, "Signet cell carcinoma of the colon in a 17year old child," Journal of Strength and Conditioning Research, vol. 9, article 3, 2012.

[19] H. E. Achneck, S. K. Pradhan, S. M. Kavic, and W. E. Longo, "Primary signet-ring cell carcinoma mimicking segmental Crohn's colitis," Digestive and Liver Disease, vol. 37, no. 7, pp. 537-541, 2005. 


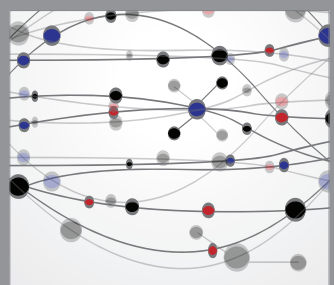

The Scientific World Journal
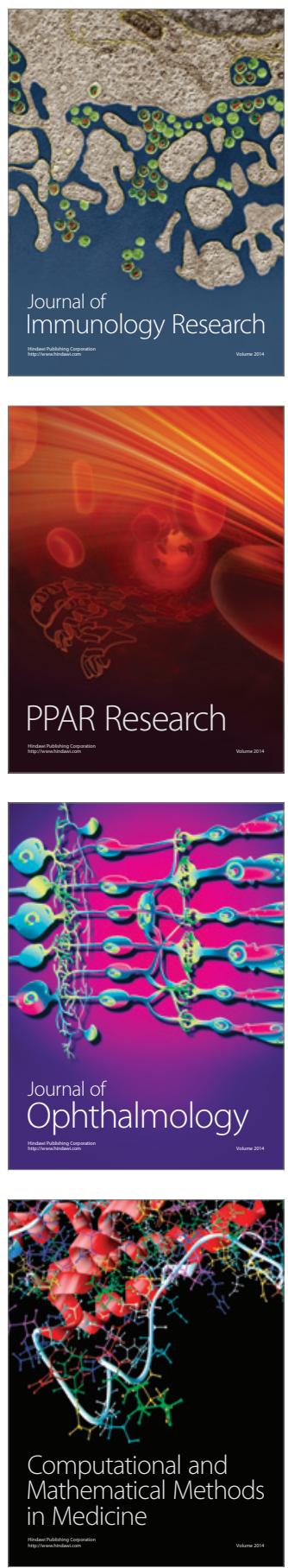

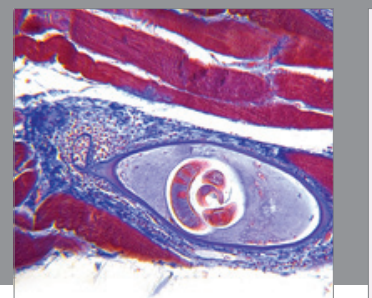

Gastroenterology

Research and Practice
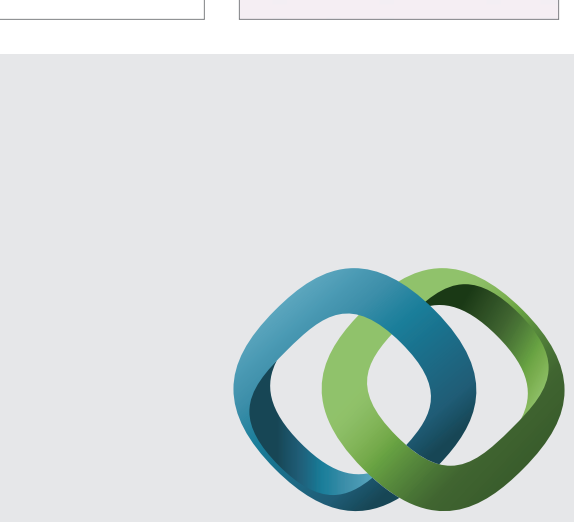

\section{Hindawi}

Submit your manuscripts at

http://www.hindawi.com
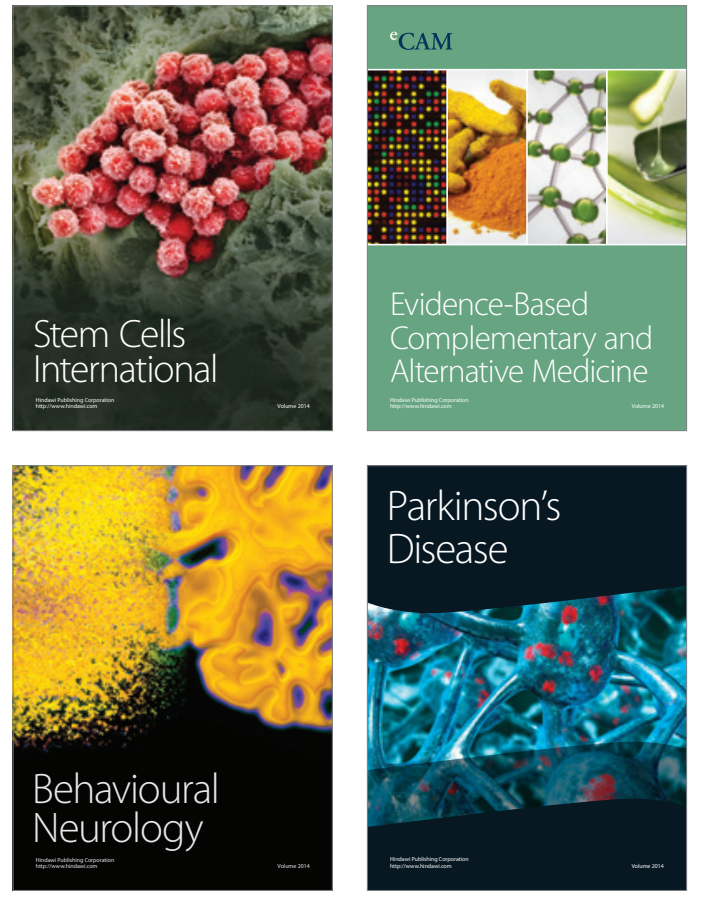
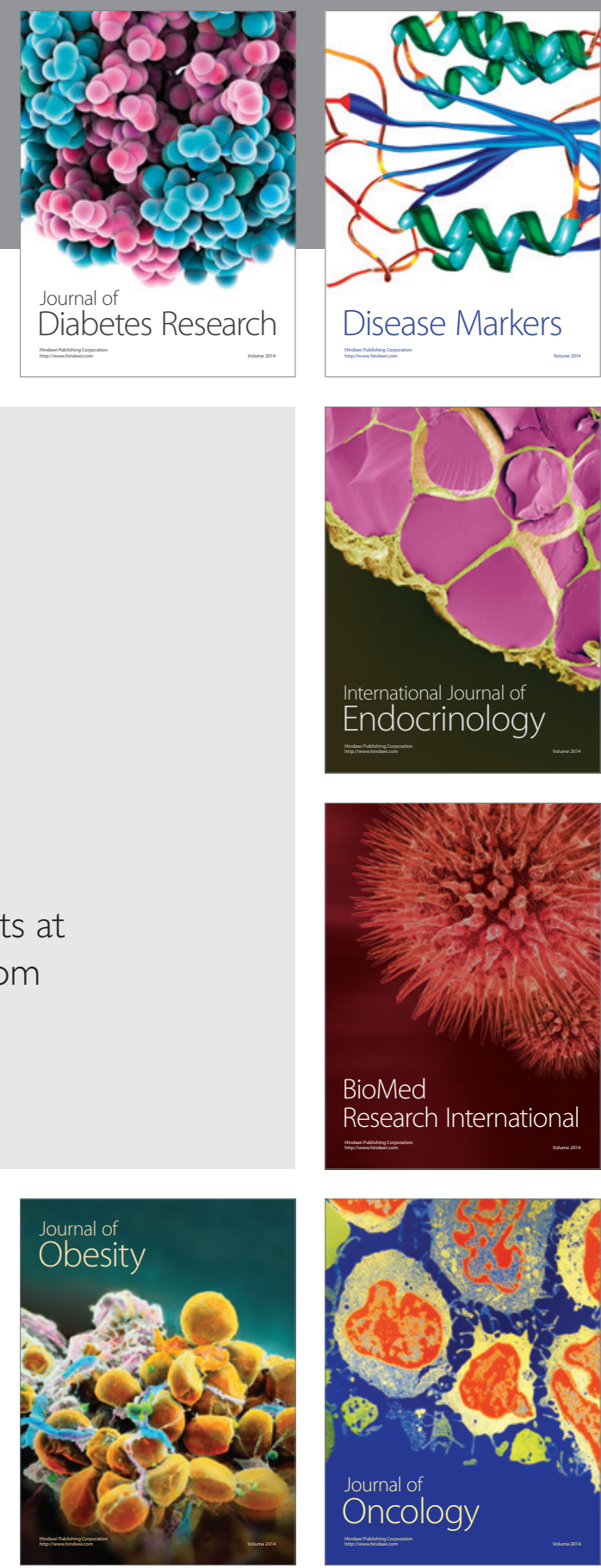

Disease Markers
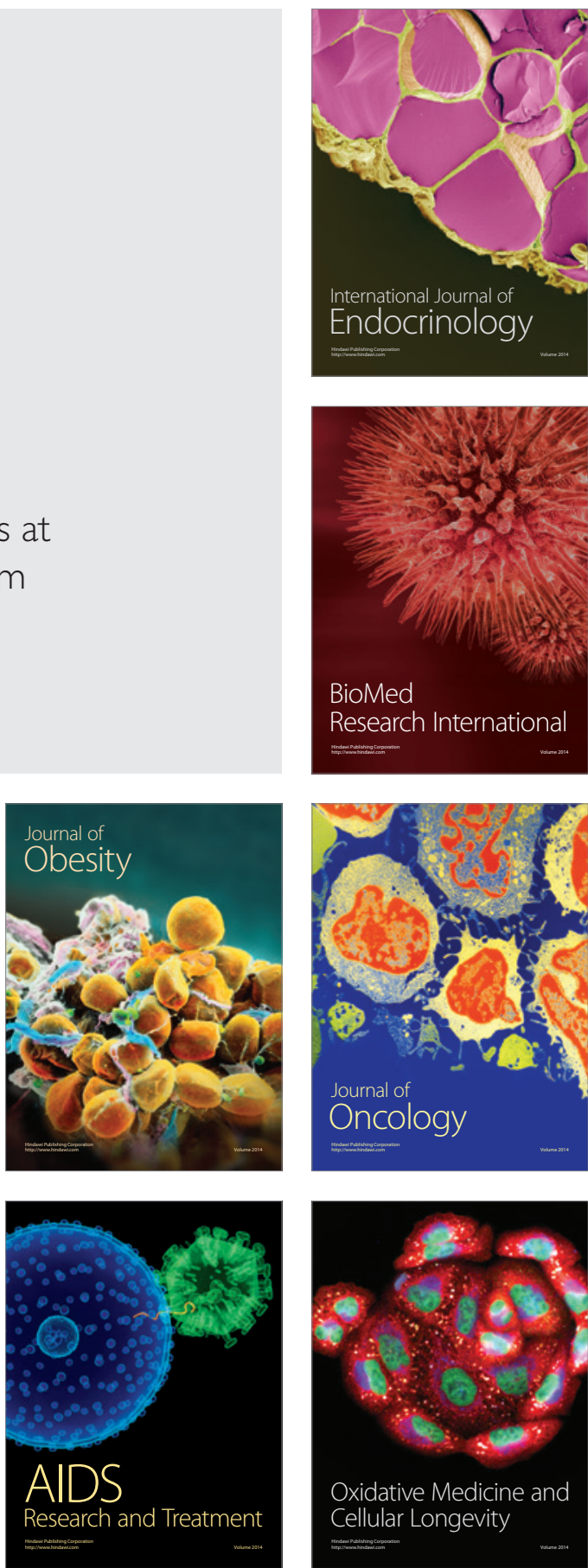